\title{
Managing the Potential of Digital Transformation of Ukraine's Economy
}

\author{
Nataliia Kasianova, Serhii Smerichevskyi, Olena Klimova, Yurii Kolbushkin
}

\begin{abstract}
The possibilities of digitalisation can become a point of growth for economic systems when the standard tools for improving efficiency begin to exhaust themselves. The main goals of digital transformation are to increase the speed of decision-making, increase the variability of processes depending on the needs and characteristics of the client, and reduce the number of employees involved in the process.

The problem of identifying the main drivers of digitalisation of the economy requires the study of the possibility of implementing digital transformation by industrial enterprises of Ukraine. A typical problem of modern domestic enterprises is the gap between automated production and outdated forms of corporate management. The above mentioned determined the aim of the paper - to assess the digitalisation potential of Ukraine's economy and identify the problematic issues of digital technologies at industrial enterprises.

For the transition to the digital form of business, it is necessary to conduct a digital transformation of business entities, which implies the use of the entire pool of modern information and communication technologies.
\end{abstract}

The effectiveness of transformation processes depends not only on the power of external influences but also on the potential of enterprises and the economy as a whole to perceive these impacts. In this regard, the first stage of development of the strategy of digitalisation of the economy of Ukraine has to become a stage of an assessment of the digitalisation potential of the country.

The proposed approach to assessing the potential of digitalisation of the economy is based on the need to quantify the individual components of the digitalisation resources and catalysts, to determine their harmony under the strategic goal and taking into account the degree of involvement of the enterprise in digital processes.

Evaluation of the catalysts impact on the digitalisation of the economy is implemented using the Fuzzy Logic Theory. The structure of the model for the catalysts impact evaluation contains four submodels: model of digitalisation potential dependence on the level of professionalism and qualification factors; model of potential dependence on financial and investment state; model of dependence on the state of infrastructure support of digitalisation processes; model of dependence on management actions and organisational support.

According to the level of catalysts impact, the digitalisation potential is in the range of the average level of activation (75\%). That is, after the transformation process completed in the steady-state mode, the level of the digitalisation potential of the economy will make forced harmonic oscillations with the same frequency, but with different amplitude.

The developed model allows estimating with sufficient reliability the dynamics of the potential level of digitalisation of

Revised Version Manuscript Received on October 15, 2019.

Natalia Kasianova*, the Department of Economic Cybernetics, National Aviation University, Kyiv, Ukraine. Email: nat_kas@ukr.net

Serhii Smerichevskyi, the Department of Marketing, National Aviation University, Kyiv, Ukraine. Email: s_f_smerichevsky@ukr.net

Olena Klimova, the Department of Marketing, National Aviation University, Kyiv, Ukraine. Email: jencapriati@yandex.ru

Yurii Kolbushkin, the Department of Marketing, National Aviation University, Kyiv, Ukraine.

the Ukrainian economy at known statistical and expert values of input parameters.

Keywords: digital transformation, digitalisation catalysts, economic and mathematical model, Fuzzy Logic Theory, innovations, innovative resources, potential of digitalisation.

\section{INTRODUCTION}

Digital transformation is a global trend that is steadily penetrating all spheres of society. It concerns both the most innovative areas and rather conservative ones. It is the introduction of modern technologies in business processes to optimise and accelerate them. In practice, this means the development of advanced digital communication channels, the use of artificial intelligence to process large amounts of data, robotics and automation of routine operations, which increases productivity. In essence, digital transformation is a way to adapt to changing conditions, a way to survive in competition.

The possibilities of digitalisation can become a point of growth for economic systems when the standard tools for improving efficiency begin to exhaust themselves. The main goals of digital transformation are to increase the speed of decision-making, increase the variability of processes depending on the needs and characteristics of the client, and reduce the number of employees involved in the process (that is, decision-making chains and value creation).

Analysts from Capgemini Consulting [1] analysed more than 400 major global companies from different industries to understand what digitalisation of business means for them. The results of the study showed that financial indicators depend on the application of new technologies and management techniques:

- companies that actively use technology and new management methods, on average, operate $26 \%$ more profitable than their competitors;

- organisations that invest a lot in digital technology, but pay little attention to management, have financial performance $11 \%$ lower;

- more conservative companies, which only improve management, receive an additional $9 \%$ of profits, but can potentially get three times more with the help of digital technologies;

- those who have not yet chosen a strategy of digitalisation lose up to $24 \%$ of finance compared to other market players. 
The advantages of the digital economy mentioned above increase the interest in digital transformation in the domestic scientific community and representatives of the business. The development of Digital agenda of Ukraine [2] and the approval of the Concept of development of digital economy and society of Ukraine for 2018-2020 on its basis [3] are confirmation of the above information at the national level.

\section{LITERATURE REVIEW}

The digital transformation of the world's economies, production processes and service delivery is one of the leading trends that scientists and practitioners are exploring.

The problem of identifying the main drivers of digitalisation of the economy revealed in the scientific works of such scientists as J. Bloomberg, A. Perrot, N. Colin, E. Alm, N. Colliander, F. Deforche and others [4-6]. Among domestic scientists, V. Vyshnevskyi, V. Liashenko, N. Kraus, V. Kupriyanovskiy, V. Pilinskyi and others paid attention to the studied problem [7-11].

At the same time, it should be noted that the versatility and debatable nature of specific issues of digitalisation necessitates further studies of the prospects for the impact of digital technologies on economic development. Thus, it requires the study of the possibility of implementing digital transformation by industrial enterprises of Ukraine, determining the ways of formation of the corresponding potential.

\section{THE AIM OF THE PAPER}

The paper aims to assess the digitalisation potential of Ukraine's economy and identify the problematic issues of digital technologies at industrial enterprises.

\section{RESULTS AND DISCUSSION}

In Ukraine, there are traditional technologies, the country "inherited" from Soviet times. So, Ukraine is still not able to develop modern equipment and mass produce it. A typical problem of modern domestic enterprises is the gap between automated production and outdated corporate management. However, the transition to a fully digital enterprise, in which production, service, finance and marketing combined into a single system, is challenging. The most difficult is to rebuild enterprises of old industries. Many such plants still operate equipment from the 1980s, which does not allow obtaining data on production processes. Significant investments are needed to overcome this obstacle. It is cheaper not to upgrade, but to build a new plant. The level of development of technologies in the world is such that if earlier, some functions were automated: accounting, warehouse, design, and so on, today, fully digital production management is possible.

An essential condition for the success and one of the difficult stages of the development of the digital sector of the economy is the simplification of the business environment and the maximum reduction of costs in the interaction of the population and business with the state. In Ukraine, there is no model for assessing the economic impact of information and communication technologies (ICT) on specific industries and spheres of life. The current system of digital statistics relates only to the number of imported machinery and equipment and the volume of exports of services of IT companies. There are also no official data on the digital coverage of the country's infrastructure and the level of consumption of relevant services. At the same time, the share of the digital economy in Ukraine's GDP is continually growing (Table-I)

Table-I: Indicators of digitalisation of the Ukrainian economy [12]

\begin{tabular}{|l|l|l|}
\hline Year & $\begin{array}{l}\text { Share of the } \\
\text { digital economy } \\
\text { in GDP, \% }\end{array}$ & $\begin{array}{l}\text { Domestic market } \\
\text { (ICT consumption), \$ } \\
\text { million }\end{array}$ \\
\hline 2010 & 3.06 & 4178.61 \\
\hline 2011 & 2.98 & 4859.49 \\
\hline 2012 & 3.05 & 5355.43 \\
\hline 2013 & 3.24 & 5935.12 \\
\hline 2014 & 2.76 & 3636.14 \\
\hline 2015 & 3.64 & 3299.82 \\
\hline 2016 & 3.87 & 3606.79 \\
\hline 2017 & 3.64 & 4085.04 \\
\hline $2018^{\text {a }}$ & 4.77 & 6236.94 \\
\hline $2019^{\text {a }}$ & 7.34 & 10089.30 \\
\hline
\end{tabular}

${ }^{\mathrm{a}}-$ The forecast is built by the authors.

Naturally, the way of digitalisation of each enterprise will be individual in approaches and time. Still, the transformation is necessary, and the main thing for the heads of enterprises is the awareness of the suitability and relevance of measures for the active introduction of new technologies into production. The creation by the state of an external climate focused on the digitalisation of enterprises through the formation of a regulatory framework, as well as natural processes of digitalisation of society, will ensure shortly the elimination of enterprises that produce low-quality products and are not interested in improving the competitiveness of production. In our opinion, within $7-10$ years, most domestic enterprises should bring their capabilities in line with the requirements of the state in the field of digitalisation.

For the transition to the digital form of business, it is necessary to conduct a digital transformation of business entities, which implies the use of the entire pool of modern ICT. If earlier in production the optimisation of its separate phases or stages was only considered, today in the framework of digital transformation and the creation of a digital enterprise an end-to-end process is analysed, today in the framework of digital transformation and the creation of a digital enterprise an end to end process is analysed, that includes not only the production stages from the idea, development, design, procurement to the manufacture of products, but also related infrastructure support: financial activities, human resources, logistics, operation, but also related infrastructure support: financial activities, human resources, logistics, operation, support, partner network, subcontractors and the like.

To find the most effective single algorithm of the digital transformation of the Ukrainian economy, it is necessary to consider the main directions of digitalisation of industrial enterprises: 
- general directions - production, management organisation, logistics, sales system and personnel policy;

- related areas of digitalisation have blurred boundaries and reflect infrastructure.

Thus, digital enterprise involves the digitalisation and integration of vertical processes across the enterprise, from product development and procurement to manufacturing, logistics and in-service. In turn, the horizontal integration of the digital enterprise extends beyond internal operations to include suppliers, consumers and all key partners across the value chain. It makes sense to use a variety of technologies, from tracking and monitoring devices to complex planning integrated with real-time execution. All this is done based on an appropriate digital platform and altogether makes up the so-called digital ecosystem of the digital enterprise.

The effectiveness of transformation processes depends not only on the power of external influences but also on the potential of enterprises and the economy as a whole to perceive these impacts. In this regard, the first stage of development of the strategy of digitalisation of the economy of Ukraine has to become a stage of an assessment of the potential of digitalisation. Under the potential of digitalisation of the economy of Ukraine, we will understand the combination of resources and catalysts that make it possible to use these resources to achieve the goal of the digital transformation of the system, increasing its competitiveness in the digital economy.

Digitalisation resources $(D R)$ determine the ability of the digitalisation system and act as its sources (personnel, scientific and technical, production and technological, financial and economical, etc.). Catalysts $(C)$ are conditions that ensure optimal use of available resources to achieve the strategic goal of digitalisation of the country's economy. They accelerate the transformation of innovative ideas into innovative products (or processes). In our opinion, the catalysts should include the motivational mechanism, the digital culture of enterprises, the level of readiness of organisational and managerial elements for digitalisation.

The proposed approach to assessing the potential of digitalisation of the Ukrainian economy is based on the need to quantify the individual components of the $D R$ and $C$, to determine their harmony under the strategic goal and taking into account the degree of involvement of the enterprise in digital processes.

Interpretation of the potential level of digitalisation of the economy of Ukraine is advisable to carry out based on E. Harrington's desirability function. To organise the indicators for the selected areas of research, each of them is rated ( 0 to 1) on the scales of assessment presented for each indicator of the potential evaluation.

The data of the State statistics service were used as the initial information to characterise the potential of digitalisation of the Ukrainian economy. In the proposed model, for each component of the digitalisation, potential significance coefficients are introduced selected depending on the significance of the indicator by expert means. The formula for calculating the level of digitalisation potential is as follows:

$D P=0.32 D R 1+0.2 D R 2+0.09 D R 3+0.07 D R 4+0.19 D R 5+0.13 D R 6,(1)$

$D R 1$ - the share of enterprises using digital technologies in economic activity;
$D R 2$ - innovation costs, \% of GDP;

$D R 3$ - the share of innovative products in total production;

$D R 4$ - the state of the production sector of the country (the level of depreciation of fixed assets, which determines the possibility of their use in the process of digitalisation);

DR5 - the share of ICT in the country's GDP, \%;

DR6 - the level of education of the population of Ukraine (the proportion of the population $(\%)$ aged 21 years and older who has complete and primary higher education).

The obtained integral indicator reflects the level of digitalisation potential in dynamics shown in Table-II.

Table-II: Changing the level of digitalisation potential development in Ukraine

\begin{tabular}{|l|l|l|l|l|l|l|l|l|l|}
\hline & $\begin{array}{l}\mathbf{2 0 1} \\
\mathbf{0}\end{array}$ & $\mathbf{2 0 1}$ & $\mathbf{1 0 1}$ & $\mathbf{2 0 1}$ & $\mathbf{2 0 1}$ & $\mathbf{2 0 1}$ & $\mathbf{2 0 1}$ & $\mathbf{2 0 1}$ & $\mathbf{2 0 1}$ \\
$\mathbf{6}$ & $\mathbf{6}$ & $\mathbf{4}$ & $\mathbf{5}$ & $\mathbf{6}$ & $\mathbf{7}$ \\
\hline$D R 1$ & 11.5 & 12.8 & 13.6 & 12.9 & 12.1 & 15.2 & 16.6 & 14.3 & 15.6 \\
\hline$D R 2$ & 0.75 & 0.65 & 0.67 & 0.7 & 0.6 & 0.55 & 0.48 & 0.45 & 0.34 \\
\hline$D R 3$ & 3.8 & 3.8 & 3.3 & 3.3 & 2.5 & 1.4 & 1.05 & 0.7 & 0.8 \\
\hline$D R 4$ & 74.9 & 75.9 & 76.7 & 77.3 & 83.5 & 60.1 & 58.1 & 55.1 & 60.6 \\
\hline \multirow{2}{*}{$D R 5$} & 3.06 & 2.98 & 3.05 & 3.24 & 2.76 & 3.64 & 3.87 & 3.64 & $\begin{array}{l}3.80 \\
\end{array}$ \\
\hline$D R 6$ & 24.2 & 25.6 & 27.3 & 29.0 & 29.1 & 29.3 & 28.6 & 28.7 & 28.7 \\
\hline \multirow{2}{*}{$D P$} & 0.31 & 0.31 & 0.32 & 0.33 & 0.30 & 0.33 & 0.32 & 0.31 & 0.30 \\
& 7 & 5 & 3 & 3 & 1 & 2 & 8 & 5 & 6 \\
\hline
\end{tabular}

The table data show a steady trend of digitalisation potential. According to E. Harrington's desirability function, the potential level of digitalisation of Ukraine is below average. The assessment reflects the following facts: the activity on digitalisation of the economy is conducted at an average level, educational activities are carried out at a rather high level, but there is no particular impact on the potential level of digitalisation.

When planning digitalisation strategies, it is advisable focusing efforts to activate the most influential internal and external factors of digitalisation of the economy. The use of econometric analysis of the digitalisation potential enabled to identify the most critical $D R$ and build a multiple regression model:

$$
D P=0.107+0.005 D R 1+0.125 D R 2+0.022 D R 5
$$

The calculated coefficient of multiple determination $R^{2}=0.945$ proves that the three selected factors explain the $94.5 \%$ variation in the estimation of the digitalisation potential. The allocation of these factors can be explained as follows:

- enterprises using digital technologies in economic activities are the basis of digitalisation of the country's economy, forcing competitors to carry out similar processes;

- the costs of enterprises and the state for innovation contribute to the development of innovation processes, and digitalisation is an integral part of them;

- the level of development and demand for digital technologies in the world have a positive impact on the growth of enterprises - developers of ICT in Ukraine, which in turn stimulates the activation of digital processes in the country. 
Nevertheless, the level of potential for digitalisation of the economy depends not only on the available resources of digitalisation but also on the catalysts that ensure the optimal use of these resources, stimulate the activation of digital transformation. It is proposed to assess the catalysts of digitalisation using Fuzzy Logic Theory, which uses linguistic variables along with quantitative ones.

The list and structure of catalysts of the digital transformation of the economy of Ukraine are in Table-III.

Table-III: Model input variables and their linguistic evaluation

\begin{tabular}{|c|c|c|c|}
\hline & Indicators & Values & Terms \\
\hline \multicolumn{4}{|c|}{$\begin{array}{l}\text { The catalysts of the professional qualification development of } \\
\text { employees }\end{array}$} \\
\hline$x_{1}$ & Career growth & $\begin{array}{l}0-100 \\
\%\end{array}$ & $\begin{array}{l}\text { very low (VL); medium (M); } \\
\text { stable (ST); above average (AA); } \\
\text { high }(\mathrm{H})\end{array}$ \\
\hline$x_{2}$ & $\begin{array}{l}\text { Personal } \\
\text { responsibility } \\
\text { level }\end{array}$ & $0-50 \%$ & $\begin{array}{l}\text { low (L); medium }(\mathrm{M}) ; \text { above } \\
\text { average (AA); high }(\mathrm{H}) ; \text { very } \\
\text { high }(\mathrm{VH})\end{array}$ \\
\hline$x_{3}$ & $\begin{array}{l}\text { Cooperation } \\
\text { between } \\
\text { workers level }\end{array}$ & $\begin{array}{l}0-100 \\
\%\end{array}$ & $\begin{array}{l}\text { negative }(\mathrm{N}) ; \text { normal }(\mathrm{NO}) \text {; } \\
\text { positive }(\mathrm{P})\end{array}$ \\
\hline \multicolumn{4}{|c|}{ Financial and investment catalysts } \\
\hline$x_{4}$ & $\begin{array}{l}\text { Investment } \\
\text { activity }\end{array}$ & $\begin{array}{l}\$ 1-10 \\
\text { bln }\end{array}$ & $\begin{array}{l}\text { low (L); stable (ST); medium } \\
(\mathrm{M}) ; \text { above average (AA); high } \\
(\mathrm{H})\end{array}$ \\
\hline$x_{5}$ & $\begin{array}{l}\text { Return } \\
\text { assets }\end{array}$ & $\begin{array}{l}40-150 \\
\%\end{array}$ & $\begin{array}{l}\text { low }(\mathrm{L}) ; \text { medium }(\mathrm{M}) ; \text { above } \\
\text { average (AA); } \\
\text { high }(\mathrm{H})\end{array}$ \\
\hline$x_{6}$ & $\begin{array}{l}\text { Public finance } \\
\text { level }\end{array}$ & $\begin{array}{l}\$ 1-10 \\
\text { bln }\end{array}$ & $\begin{array}{l}\text { low (L); stable (ST); medium } \\
(\mathrm{M}) \text {; above average (AA); high } \\
(\mathrm{H})\end{array}$ \\
\hline \multicolumn{4}{|c|}{ The catalysts of infrastructure support } \\
\hline$x_{7}$ & $\begin{array}{l}\text { Institutional } \\
\text { infrastructure }\end{array}$ & $\begin{array}{l}0-100 \\
\%\end{array}$ & $\begin{array}{l}\text { negative }(\mathrm{N}) \text {; stable }(\mathrm{ST}) \\
\text { positive }(\mathrm{P})\end{array}$ \\
\hline$x_{8}$ & $\begin{array}{l}\text { Transport } \\
\text { infrastructure }\end{array}$ & $\begin{array}{l}0-100 \\
\%\end{array}$ & $\begin{array}{l}\text { negative }(\mathrm{N}) ; \text { stable }(\mathrm{ST}) ; \\
\text { positive }(\mathrm{P})\end{array}$ \\
\hline$x_{9}$ & $\begin{array}{l}\text { Service } \\
\text { infrastructure }\end{array}$ & $\begin{array}{l}0-100 \\
\%\end{array}$ & $\begin{array}{l}\text { negative }(\mathrm{N}) \text {; stable }(\mathrm{ST}) \text {; } \\
\text { positive }(\mathrm{P})\end{array}$ \\
\hline$x_{10}$ & $\begin{array}{l}\text { Information } \\
\text { environment }\end{array}$ & $\begin{array}{l}0-100 \\
\%\end{array}$ & $\begin{array}{l}\text { weak }(\mathrm{W}) \text {; stable }(\mathrm{ST}) \text {; medium } \\
(\mathrm{M}) ; \text { above average }(\mathrm{AA}) ; \\
\text { high }(\mathrm{H})\end{array}$ \\
\hline \multicolumn{4}{|c|}{ Managerial and organisational catalysts } \\
\hline$x_{11}$ & $\begin{array}{l}\text { The quality } \\
\text { management } \\
\text { system level }\end{array}$ & $\begin{array}{l}0-100 \\
\%\end{array}$ & $\begin{array}{l}\text { weak }(\mathrm{W}) ; \text { stable }(\mathrm{ST}) ; \text { medium } \\
(\mathrm{M}) ; \text { above average }(\mathrm{AA}) ; \\
\text { high }(\mathrm{H})\end{array}$ \\
\hline$x_{12}$ & $\begin{array}{l}\text { The corporate } \\
\text { culture level }\end{array}$ & $0-50 \%$ & $\begin{array}{l}\text { below average (BA); medium } \\
(\mathrm{M}) ; \text { high }(\mathrm{H})\end{array}$ \\
\hline$x_{13}$ & $\begin{array}{l}\text { Social } \\
\text { responsibility }\end{array}$ & $0-50 \%$ & $\begin{array}{l}\text { below average (BA); medium } \\
(\mathrm{M}) \text {; high }(\mathrm{H})\end{array}$ \\
\hline$x_{14}$ & $\begin{array}{l}\text { Organisational } \\
\text { support }\end{array}$ & $\begin{array}{l}0-100 \\
\%\end{array}$ & $\begin{array}{l}\text { negative }(\mathrm{N}) ; \text { normal }(\mathrm{NO}) \text {; } \\
\text { positive }(\mathrm{P})\end{array}$ \\
\hline
\end{tabular}

In building the model of catalysts for the development of the digitalisation potential of the Ukrainian economy, qualitative input parameters used $\left\{x_{1} \ldots x_{14}\right\}$, for the evaluation of which it is proposed to use the appropriate scores. The following marks are introduced: low (L), below average (BA), average (A), above average (AA), high (H) levels of the generalised output parameter. The following levels indicate possible values of the level of activation of the digitalisation potential of the country's economy: $d_{1}-$ above average level of potential activation $(80-100 \%), d_{2}-$ average level of activation $(67-80 \%), d_{3}$ - below average level of potential activation $(37-67 \%), d_{4}-$ low level $(20-$ $37 \%), d_{5}-$ absolute absence of digitalisation potential activation $(0-20 \%)$. These levels considered as qualitative characteristics that determine the activation of the potential of digitalisation of the economy.
Thus, the structure of the model for assessment of the digitalisation potential of the economy of Ukraine proposed, which shows that this model contains four submodels:

1) model of digitalisation potential dependence on the level of professionalism and qualification factors;

2) model of potential dependence on financial and investment state;

3) model of dependence on the state of infrastructure support of digitalisation processes;

4) model of dependence on management actions and organisational support.

The results of the simulation (Fig. 1) allow concluding that the indicators of the level of digitalisation potential of the Ukrainian economy based on expert assessment and those based on a harmonious concept differ. If the level of digitalisation resources potential is estimated as below average, according to the level of catalysts, the digitalisation potential is in the range of the average level of activation $(75 \%)$. That is, after the transformation process completed in the steady-state mode, the output value of the $D P$ (the level of the digitalisation potential of the economy) will make forced harmonic oscillations with the same frequency, but with a different amplitude and phase-shifted relative to the input oscillations at an angle $d$, the interval value of which will determine the boundaries of the development of digitalisation processes in the country.

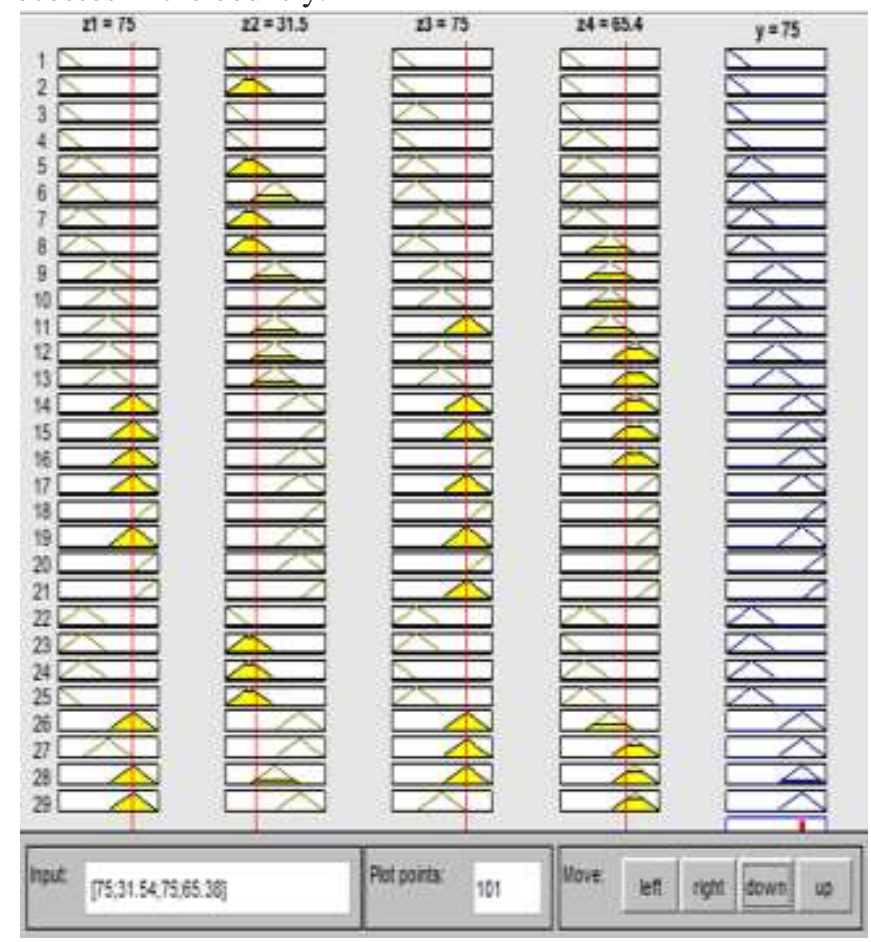

Fig. 1. Visualisation of a fuzzy model for catalysts evaluation

The developed model allows estimating with sufficient reliability the dynamics of the potential level of digitalisation of the Ukrainian economy at known statistical and expert values of input parameters. Taking into account the results of the simulation, we can identify the main problems of digitalisation of the economy of Ukraine: 
- personnel problem - specialists who work currently are not ready for changes;

- changing the structure of the labour market in favour of specialists who work with information;

- outdated education system - the knowledge provided does not meet the requirements of production digitalisation;

- deficient lifetime level of fixed assets of enterprises and organisations for the transformation processes implementation;

- lack of government support for the digitalisation of industry.

For the implementation of digital management of the country's economy, data on the current state of all resources and objects must be simultaneously available in real-time of all information systems that are associated with various stages of digitalisation of the economy. Besides, the key to digital transformation is not an automated work with structured document flow but rather the integration of enterprise unstructured content management capabilities with analytics.

The great advantage of digitalisation is that it can be implemented in stages. So, it is possible to equip enterprises with cyber-physical systems without production stop. The above-mentioned includes providing the necessary sensors, installing system components with miniature servers and replacing the bus system. That is, one can start with individual machines, and then convert the entire plant. The situation is similar with the digitalisation of not only production processes. Thus, educational and infrastructure projects can also be implemented gradually, regardless of changes in related processes.

The digitalisation of enterprises and organisations is carried out by creating a digital twin. So, digital "casts" of production include all indicators of the equipment and standards of operations performance. The digital twin will allow not only to see the processes in detail but also to identify repetitive operations that can be automated or robotised. With its help, management will not only be able to respond to certain situations in real-time but also to predict them using predictive analytics.

\section{CONCLUSION}

However, the digitalisation of Ukraine's economy is very real. But it should be borne in mind that the potential of digitalisation requires significant financial and investment support and organisational innovations.

In turn, the development of the potential of digitalisation of the Ukrainian economy through the implementation of all these conditions will increase the productivity of the entire economic system of the state and gain additional competitive advantages in the global digital world.

\section{REFERENCES}

1. "Digital technology manufactures a new future at BHGE plants".

Available: https://capgemini.com/client-story/digital-tech nology- manufactures-a-new-future-at-bhge-plants/

2. "Digital agenda of Ukraine-2020 ("Digital agenda"-2020). Conceptual framework (version 1.0). Priority areas, initiatives, projects of digitalisation of Ukraine until 2020". Available: https://ucci.org.ua/uploads/files/ 58e78ee3c3922.pdf
3. "About approval of the Concept of development of digital economy and society of Ukraine for 2018-2020 and the approval of the plan of actions for its implementation". Available: https://kmu.gov.ua/ua/npas/proshvalennya-koncepciyi-rozvitku-cifrovoyi-ekonomiki-tas uspilstva-ukrayini-na-20182020-roki-ta-zatverdzhennyaplanu-zahodiv-shodo-yiyi-realizaciyi

4. J. Bloomberg, "Digitization, Digitalization, And Digital Transformation: Confuse Them At Your Peril". Available: https://www.forbes.com/sites/ jasonbloomberg/2018/04/29/digitization-digitalizationan d-digital-transformation-confuse-them-at-your-peril/\#1e1 fe $3 \mathrm{~d} 02 \mathrm{f} 2 \mathrm{c}$

5. N. Colin, A. Landier, P. Mohnen, et al., "The digital economy," Notes du conseil d'analyse économique, vol. 26, pp. 1-12, 2015.2 Available: https://cairn-int.info/article-E_NCAE_026_-0001-the-digital -economy.htm

6. E. Alm, N. Colliander, F. Deforche et al., Digitizing Europe. Why northern european frontrunners must drive digitization of the EU economy. Stockholm: BCG, 2016.

7. V.P. Vyshnevskyi, S.Y. Kniazev, "Smart promyshlennost': perspektivy i problemy" ["Smart industry: prospects and challenges,"] The Economy of Ukraine, No. 7, pp. 22-37, 2017. (in Russian)

8. V.I Liashenko, O.S. Vyshnevskyi, Tsyfrova modernizatsiia ekonomiky Ukrainy yak mozhlyvist proryvnoho rozvytku [Digital modernisation of Ukraine's economy as an opportunity for breakthrough development]. Kyiv: NAS of Ukraine, The Economy of Industry Institute, 2018. (in Ukrainian)

9. N.M. Kraus, O.P. Holoborodko, K.M. Kraus, "Tsyfrova ekonomika: trendy ta perspektyvy avanhardnoho kharakteru rozvytku" ["Digital economy: trends and prospects of advanced development,"] Efficient economy, No. 1, 2018. [Online]. Available: http://www.economy.nayka.com.ua /pdf/1_- 2018/8.pdf. [Accessed October 10, 2019]. (in Ukrainian)

10. V. P. Kupriyanovskiy, A. P. Dobrynin, S. A. Sinyagov, et al., "Tselostnaya model' transformatsi $\mathrm{v}$ tsifrovoy ekonomike - kak stat' tsifrovymi liderami" ["A holistic model of transformation in the digital economy - how to become digital leaders,"] International Journal of Open Information Technologies, vol. 5, no. 1, pp. 26-33, 2017. (in Russian)

11. S.M. Veretiuk, V.V. Pilinskyi, "Vyznachennia priorytetnykh napriamkiv rozvytku tsyfrovoi ekonomiky v Ukraini" ["Determining the priority directions of development of the digital economy in Ukraine,"] Scientific Notes of The Ukrainian Research Institute of Communications, No. 2, pp. 51-58, 2016. (in Ukrainian)

12. State Statistics Service of Ukraine. Available: http://www.ukrstat.gov.ua/

13. Minashkin V.G., Prokhorov P.E., "Statisticheskiy analiz ispol'zovaniya tsifrovykh tekhnologiy v organizatsiyakh: regional'nyy aspect" ["Statistical analysis of the use of digital technologies in organisations: regional aspect,"] Statistics and Economics, vol. 5, No. 15, pp. 51-62, 2018. (in Russian) 


\section{AUTHORS PROFILE}

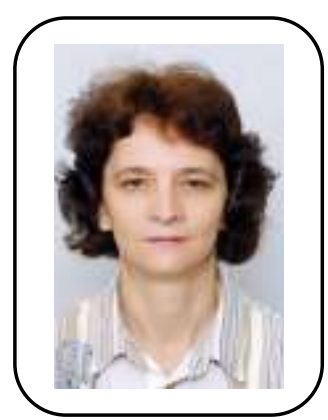

Nataliia Kasianova - Doctor of Economics, professor, professor of the Department of Economic Cybernetics at National Aviation University (Kyiv, Ukraine).

ORCID ID: 0000-0001-7729-2011.

Education: Donetsk State University (1992), Donetsk, Ukraine. N. Kasianova has more than 170 scientific papers, including 10 monographs, and 6 textbooks. The main scientific interests of N. Kasianova are: problems of management of industrial enterprises development, management of complex systems in the chaotic conditions, the controlled chaos of economic systems. N. Kasianova has developed such academic subjects: "Economic Cybernetics", "Information Systems and Technologies in Management", "Operation Research", "Mathematical Models of Economic Dynamics", "Modeling in the Management of Socio-Economic Systems".

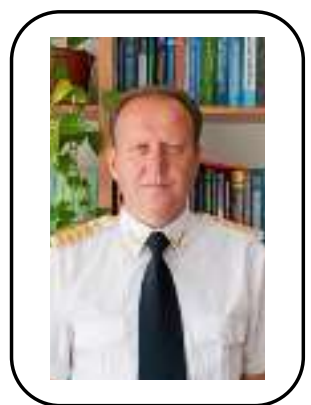

Serhii Smerichevskyi - Doctor of Economics, professor, professor of the Marketing Department at National Aviation University (Kyiv, Ukraine), corresponding member of the

Academy of Economic Sciences of Ukraine.

ORCID ID: 0000-0003-2102-1524.

Education: Donetsk Polytechnical Institute (1984), Donetsk, Ukraine. S. Smerichevskyi has more than 200 scientific papers, including 13 monographs, and 15 textbooks. S Smerichevskyi supervises the scientific work of Ph.D. students and doctoral students. The main scientific interests of S. Smerichevskyi are: economics and management of enterprises, marketing issues, economics of industry. S. Smerichevskyi has developed such academic subjects: "Strategic Marketing", "Cross-Cultural Marketing".

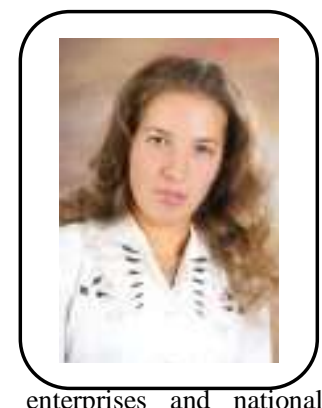

Olena Klimova - Candidate of Economics, associate professor of the Marketing Department at National Aviation University (Kyiv, Ukraine).

ORCID ID: 0000-0002-0387-3523.

Education: Donetsk State University of Management (2008), Donetsk, Ukraine. O. Klimova has more than 150 scientific papers, including 5 monographs, and 5 textbooks. The main scientific interests of O. Klimova are: economics and management of economy, strategic management, corporate management. O. Klimova has developed such academic subjects: "Fundamentals of Marketing in Transport", "Methods of Labour Processes Management".

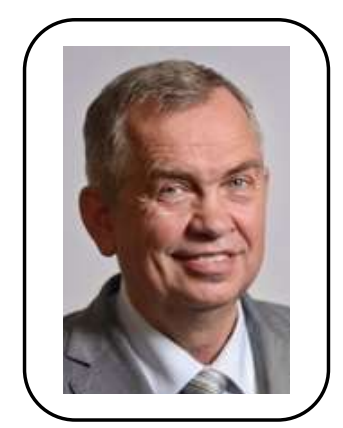

Yurii Kolbushkin - Doctor of Economics, associate professor, professor of the Marketing Department at National Aviation University (Kyiv, Ukraine).

ORCID ID: 0000-0003-3192-2385.

1. Education: Kyiv Institute of Kyiv National Economy Institute named after D.S. Korotchenko (1983), Kyiv, Ukraine. $\mathrm{Yu}$. Kolbushkin has more than 60 scientific papers, including 7 monographs, and 4 textbooks. The main scientific interests of

Yu. Kolbushkin are: the management analysis efficiency of material and financial flows of oil and gas complex. Yu. Kolbushkin has developed such academic subjects: "Marketing", "Brand-Management". 